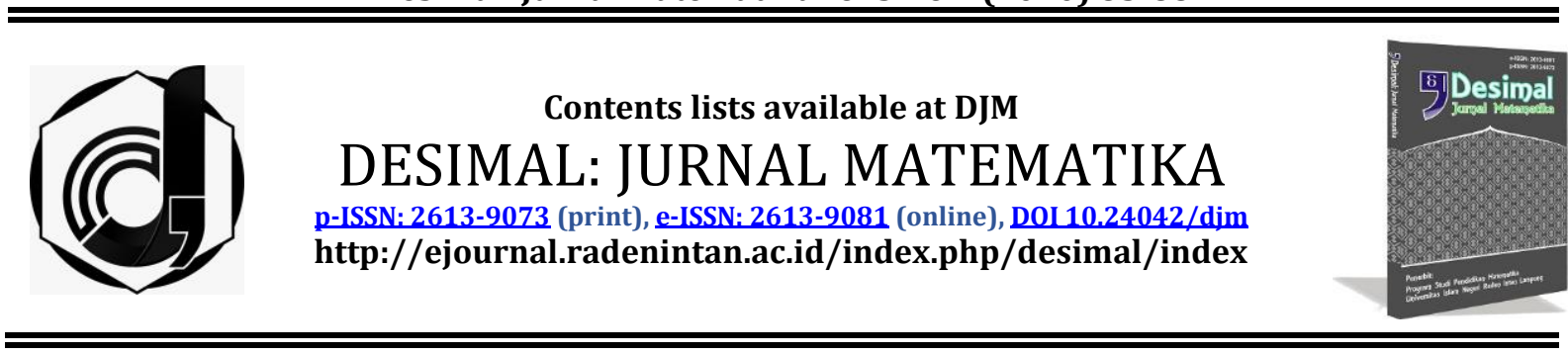

\title{
Mathematical reasoning abilities: The Impact of Novick's Learning and Somatic, Auditory, Visual, Intellectual Learning Styles
}

\author{
Muhamad Yasin ${ }^{1,}$, Nasiroh $^{2}$, Abi Fadila², Sitti Hartinah ${ }^{3}$, Novalia $^{4}$ \\ ${ }^{1}$ Institut Agama Islam Negeri Kediri, Indonesia \\ ${ }^{2}$ Universitas Islam Negeri Raden Intan Lampung, Indonesia \\ 3Universitas Pancasakti Tegal, Indonesia \\ ${ }^{4}$ Universitas Saburai, Indonesia
}

\section{ARTICLE INFO}

\section{Article History}

Received : 19-07-2019

Revised : 23-10-2019

Accepted : 25-01-2020

Published : 31-01-2020

\section{Keywords:}

SAVI Learning Style

Novick Learning

Mathematical Reasoning

${ }^{*}$ Correspondence: E-mail: yasinmuhammad106@yahoo.com

Doi:

$\underline{10.24042 / \operatorname{djm} . v 3 i 1.4907}$

\begin{abstract}
Every life needs a very important role especially the role in education. Improving the quality of education can be pursued by the use of appropriate learning models so as to improve students' reasoning abilities. The purpose of this study was to determine the differences in the influence of Novick's learning model and the learning model that is centered on educators on students' mathematical reasoning abilities, Knowing the interaction between learning models and SAVI learning styles (Somatic, Auditory, Visualization, Intelectually) on mathematical reasoning abilities learners. This research uses the Quasy Experiment Design method. The results obtained from this study are that learning by using Novick's learning model is more effective against mathematical reasoning for students, there is no interaction between Novick's learning model and SAVI learning style on mathematical reasoning abilities.
\end{abstract}

http://ejournal.radenintan.ac.id/index.php/desimal/index

\section{INTRODUCTION}

Activities in every life need a very important role, especially the role in education, where education can direct sustainability in life. For example in facing the era of globalization regarding technological advances that are so rapid (Maskur dkk. 2020). This is inseparable from the existence of mathematics, by having the ability in mathematics one can think logically in solving problems that exist in daily life, one of the problems that can be solved is about mathematical reasoning.

Mathematics learning is very closely related to mathematical reasoning, but mathematical reasoning in learning 
mathematics has not been able to change the affective and cognitive aspects such as mathematics learning achievement for the better. Achievement is a result of efforts that have been made in achieving certain results of work and time (Fadila 2015).

Research on mathematical reasoning has previously been widely studied including analysis of mathematical reasoning and student learning independence (Isnaeni dkk. 2018) there is an increase in students' mathematical abilities with open-ended (Bernard dan Chotimah 2018) and there are studies of various learning models for increasing mathematical reasoning abilities (Yusdiana dan Hidayat 2018; Saxton dkk. 2019; Sukirwan, Darhim, dan Herman 2018; Badjeber 2017; Rahmawati 2017; Lithner 2017; Maskur dkk. 2020; Ayal dkk. 2016)

Social skills in life are skills that must be possessed by every individual. One learning model that can improve social skills and build its own knowledge is the Novick learning model. Research on Novick's learning model has also been widely studied, there is the influence of the Novick learning model on students' cognitive abilities (Nurhayati dkk. 2019) Besides that, there is an influence of the Nonvick learning model on some students' abilities (Najib 2019; Prayitno dan Sugiharto 2017; Rezeki 2017; Yohansa 2018; Alatubir dan Rahman 2019)
In addition to learning models that can affect students 'mathematical reasoning abilities, there are also learning styles that can affect students' mathematical reasoning. One learning style that can affect students' mathematical reasoning is the SAVI learning style. SAVI learning styles have been widely studied before, including the effect of SAVI learning styles on problem solving abilities (Sugesti, Simamora, dan Yarmayani 2018) SAVI learning style with the development of learning tools (Wijayanti dan Sungkono 2017)

Based on some previous research, it can be seen that the renewal of this article is the link between Novick's learning model and SAVI's learning style.

\section{METHOD}

This type of research used in this study is quasy experiment with posttest only control design. This research consists of an experimental class and a control class, where the experimental class uses the Novick model while the control class uses the conventional model. The variables in this study are variables (X1) in the form of learning methods and (X2) in the form of SAVI Learning Style, then for the dependent variable (Y) in the form of mathematical reasoning abilities. The research design that will be used in this study is as follows.

Table 1. Research design

\begin{tabular}{|c|c|c|c|c|}
\hline \multirow[t]{2}{*}{ Method $\left(A_{i}\right)$} & \multicolumn{4}{|c|}{ SAVI Learning Style (Bi) } \\
\hline & $\begin{array}{c}\text { Somatic } \\
\text { (B1) }\end{array}$ & $\begin{array}{c}\text { Audio } \\
\text { (B2) }\end{array}$ & $\begin{array}{c}\text { Visual } \\
\text { (B) }\end{array}$ & $\begin{array}{c}\text { Intellectual } \\
\text { (B4) }\end{array}$ \\
\hline Novick $\left(A_{1}\right)$ & $\mathrm{A}_{1} \mathrm{~B}_{1}$ & $\mathrm{~A}_{1} \mathrm{~B}_{2}$ & $\mathrm{~A}_{1} \mathrm{~B}_{3}$ & $\mathrm{~A}_{1} \mathrm{~B}_{4}$ \\
\hline Conventional $\left(\mathrm{A}_{2}\right)$ & $\mathrm{A}_{2} \mathrm{~B}_{1}$ & $\mathrm{~A}_{2} \mathrm{~B}_{2}$ & $\mathrm{~A}_{2} \mathrm{~B}_{3}$ & $\mathrm{~A}_{2} \mathrm{~B}_{4}$ \\
\hline
\end{tabular}

This study with a population of all eighth grade students of SMPN 19 Bandar Lampung with random sampling. The researcher conducted an analysis prerequisite test to analyze the data obtained using the normality and homogeneity test, then test the hypothesis using the two-way Anova test. This test is used to compare the means of several groups.

\section{RESULTS AND DISCUSSION}

Based on the research design, as for the results of the statistical analysis of the 
final test (posttest) mathematical reasoning ability on statistical material can be seen in Table 2:

Table 2. Description of Observation Data of Mathematical Reasoning Ability of Students in Experimental and Control Classes

\begin{tabular}{|c|c|c|c|c|c|c|c|}
\hline \multirow{2}{*}{ Class } & \multirow{2}{*}{$\mathbf{X}_{\text {maks }}$} & \multirow{2}{*}{$\mathbf{X}_{\min }$} & \multicolumn{3}{|c|}{ Measuring Central Tendency } & \multicolumn{2}{|c|}{ Size of Group Variance } \\
\hline & & & $\bar{x}$ & Me & Mo & $\boldsymbol{R}$ & $s$ \\
\hline Experiment & 86 & 48 & 73 & 74 & 73 & 38 & 10.325 \\
\hline Control & 70 & 11 & 36 & 33 & 27 & 59 & 15.179 \\
\hline
\end{tabular}

Based on Table 2 can be seen the results of data from two classes of research. Based on the centralization rules show that Novick's learning model more influences students' mathematical reasoning ability compared to conventional learning models, in this case indicated by the mean and median values in the experimental class that uses novick learning model is greater than the control class that uses conventional learning models.

Table 3. Data Description Observations Questionnaire SAVI Learning Style

\begin{tabular}{ccccccc} 
Class & $\overline{\boldsymbol{x}}$ & $\mathbf{S}$ & Somatic & \multicolumn{2}{c}{ Learning Style Criteria } \\
Experiment & 84.50 & 9.67 & 2 & 14 & Visualization & Intellectually \\
Control & 83.33 & 9.09 & 2 & 20 & 3 & 2 \\
\hline
\end{tabular}

Based on Table 3 shows the influence of SAVI learning styles on students' mathematical reasoning abilities.

Table 4. Summary Analysis of Two-Way Variance Analysis

\begin{tabular}{lccccccc}
\multicolumn{1}{c}{ Source } & JK & dK & RK & F $_{\text {count }}$ & Ftable $_{\text {A }}$ & A & Conclusion \\
Learning (A) & 7955.108 & 1 & 7955.108 & 47.452 & 4.043 & 0.05 & Ho $_{\text {Rejected }}$ \\
Learning style (B) & 1427.300 & 3 & 475.767 & 2.838 & 2.798 & 0.05 & Ho $_{0}$ Rejected \\
Interaction (AB) & 346.757 & 3 & 115.586 & 0.689 & 2.798 & 0.05 & $\mathrm{H}_{0}$ Accepted \\
Error & 8046.974 & 48 & 167.645 & & & & \\
Total & 17776.139 & 55 & & & & &
\end{tabular}

Based on Table 4, it was found that $F_{a}=$ 47.452 and a significance level of 0.05 was obtained $F_{(0.05 ; 1 ; 48)}=4.043$ so that $F_{a}>$ $F_{(0.05 ; 1 ; 48)}$ which shows $\mathrm{H} 0 \mathrm{~A}$ rejected means that there is an influence of Novick's learning model on mathematical reasoning abilities.

The value on $F_{b}=2.838$ with a significance level 0.05 obtained $F_{(0.05 ; 3 ; 48)}=2.798$ so that $F_{b}>F_{(0.05 ; 3 ; 48)}$ which shows $\mathrm{H}_{0 \mathrm{~B}}$ rejected means that there is an influence of SAVI learning styles on mathematical reasoning abilities.
Obtained a value $F_{A B}=0.689$ with a significance level 0.05 obtained $F_{(0.05 ; 3 ; 48)}$ $=2.798$ so that $F_{A B}>F_{(0.05 ; 3 ; 48)}$ which shows $\mathrm{H}_{0 \mathrm{AB}}$ accepted means that there is no interaction between Novick's learning model and SAVI learning style on mathematical reasoning abilities.

Reviewing previous research states that Novick's learning model can affect the mathematical representation ability of students which shows that Novick's learning model is better than conventional learning (Rezeki 2017). Besides being able 
to improve the mathematical representation of Novick's learning models, it can also affect the ability of understanding concepts and student motivation when combined with edutainment media (Najib 2019). Enhancing students' cognitive abilities can also be improved through Novick's learning model (Nurhayati dkk. 2019). This shows that Novick's learning model can improve some students' abilities.

Based on the results of this study that there is an influence between Novick's learning model on mathematical reasoning abilities. The influence given by Novick's learning model is because this learning model uses conceptual steps where students can develop their own knowledge so that in memory storage knowledge can last longer than usual and can develop various abilities of thinking of students incarnate scientific thinking and can also produce students are more active when the learning process.

There is no significant influence of conventional learning models on mathematical reasoning ability because the teaching and learning process in the control class only interacts with the delivery of learning material and students only listen, listen, and record what has been said by the researcher and the absence of conceptual steps applied to the learning model conventional.

Based on this, students who apply the Novick learning model produce mathematical reasoning abilities that are better than students who apply conventional learning models.

Reflecting on previous research In addition to Novick's learning model there is an open-ended approach that also affects mathematical reasoning abilities (Bernard dan Chotimah 2018), students' mathematical reasoning abilities will have a significant effect when using the Teams Games Tournament (TGT) learning model when compared to the use of the
Numbered Head Together (NHT) learning model (Rahmawati 2017).

In addition to learning models that can affect students 'mathematical reasoning abilities, there are also learning styles that can affect students' mathematical reasoning. One style that can influence mathematical reasoning ability is the SAVI learning style. This can be seen from the results of the posttest given at the end of the lesson.

Based on observations on the learning process that uses Novick's learning model or conventional learning models, there are still students who have a Somatic, Auditory, Visualization, or Intelectually learning style but when the learning process students are less active and less reasoning in understanding the material so as to obtain test scores that unfavorable, while students who look mediocre, who are not too prominent in the SAVI style of learning category in the process of learning they are active and understand the material so that they get better test scores. However, the use of SAVI learning styles is better than direct learning models for improving students' mathematical problem solving abilities (Sugesti, Simamora, dan Yarmayani 2018). The SAVI learning style will be more effective in increasing distance learning in space if combined with the CPS (Creative Problem Solving) learning model (Wijayanti dan Sungkono 2017).

Based on several research tests that have been conducted, the conclusion obtained that there is no difference in the effect between the treatment of learning and learning styles of students on the ability of mathematical reasoning, then the characteristics of differences in learning styles of students to mathematics learning will be the same for each learning treatment. While the learning treatment using Novick applies the conclusion that the somatic learning style is better than the auditory learning style, visualization, and intellectually. 
Theoretically states that what can influence the ability of mathematical reasoning is seen from the learning styles of students and the delivery of material by the use of appropriate learning models by educators. In this study there is no interaction between Novick's learning model and SAVI learning style on students' mathematical reasoning abilities.

Factors that cause research results are not fulfilled, because students are less active and lack of communication between other colleagues in the learning process.

\section{CONCLUSIONS AND SUGGESTIONS}

Based on the analysis results obtained there is the influence of Novick's learning model on students' mathematical reasoning abilities. And There is an influence between students who have SAVI learning styles on students' mathematical reasoning abilities. There is no interaction between Novick's learning model with SAVI learning style on students' mathematical reasoning abilities.

The suggestions from researchers are: For educators, it is hoped that through this research educators can get to know methods of learning other than lectures namely Novick so that educators will be more motivated when innovating in learning to minimize student shortcomings and maximize students' mathematical reasoning abilities while for other researchers, it is expected the results of this study can be used as a reference in conducting research by deepening the scope and expanding research.

\section{REFERENCES}

Alatubir, Gresela, dan Bobbi Rahman. 2019. "Pengaruh Model Pembelajaran Novick Terhadap Kemampuan Pemahaman Konsep Siswa SMP" 7 (3): 15.

Ayal, C.S, Y. Kusuma, J. Sabandar, dan J.A. Dahlan. 2016. "The Enhancement of
Mathematical Reasoning Ability of Junior High School Students by Applying Mind Mapping Strategy." Journal of Education and Practice 7 (25).

Badjeber, R. 2017. "Asosiasi Kemampuan Penalaran Matematis Dengan Kemampuan Koneksi Matematis Siswa Smp Dalam Pembelajaran Inkuiri Model Alberta." JPPM 1 (2).

Bernard, Martin, dan Siti Chotimah. 2018. "Improve student mathematical reasoning ability with open-ended approach using VBA for powerpoint." International Conference on Science and Applied Science, September. https://doi.org/10.1063/1.505441 7.

Fadila, Abi. 2015. "Eksperimentasi Pendekatan Matematika Realistik Dengan Pemberian Tugas Ditinjau Dari Kemampuan Awal Terhadap Hasil Belajar Matematika." JURNAL e-DuMath 1 (2).

Isnaeni, Sarah, Lailatul Fajriyah, Evi Sri Risky, Ratni Purwasih, dan Wahyu Hidayat. $2018 . \quad$ "Analisis Kemampuan Penalaran Matematis Dan Kemandirian Belajar Siswa Smp Pada Materi Persamaan Garis Lurus." Journal of Medives 2 (1): $107-15$.

Lithner, J. 2017. “Principles for designing mathematical tasks that enhance imitative and creative reasoning." ZDM Mathematics Education, no. 49: 937-949. https://doi.org/DOI 10.1007/s11858-017-0867-3.

Maskur, Ruhban, Sumarno Sumarno, Yasinta Rahmawati, Kenny Pradana, Muhamad Syazali, Ari Septian, dan E.K Palupi. 2020. "The Effectiveness of Problem Based Learning and Aptitude Treatment Interaction in Improving Mathematical Creative Thinking Skills on Curriculum 2013." European Journal of Educational Research 9 (1). 
Desimal, 3 (1), 2020 - 88

Muhamad Yasin, Nasiroh, Abi Fadila, Sitti Hartinah, Novalia

https://doi.org/10.12973/eu-

jer.9.1.375.

Najib, Ashari. 2019. "Efektivitas Pembelajaran Konstruktivis-Novick Dengan Media Edutainment Dalam Pembelajaran Matematika" 2 (1): 9. Nurhayati, Iis, Ajo Dian Yusandika, Syarifudin Basyar, dan Yuwana Anjelinar. 2019. "Pengaruh Model Pembelajaran Novick Berbantuan LKPD Terhadap Kemampuan Kognitif Peserta Didik." Indonesian Journal of Science and Mathematics Education 2 (3): 353-62. https://doi.org/10.24042/ijsme.v2 i3.4361.

Prayitno, Baskoro Adi, dan Bowo Sugiharto. 2017. "Komparasi Model Pembelajaran Konstruktivis Metakognitif Dan Konstruktivis Novick Terhadap Berpikir Kritis Ditinjau Dari Kemampuan Akademik." INFERENSI 11 (1): 25. https://doi.org/10.18326/infsl3.v1 1i1.25-50.

Rahmawati, N.K. 2017. "Implementasi Teams Games Tournaments dan Number Head Together ditinjau dari Kemampuan Penalaran Matematis." Al-Jabar: Jurnal Pendidikan Matematika 8 (2): 12134.

Rezeki, Sri. 2017. "Meningkatkan Kemampuan Representasi Matematis Siswa Melalui Penerapan Model Pembelajaran Novick" 1 (3): 11.

Saxton, D., E. Grefenstette, F. Hill, dan Pushmeet Kohli. 2019. "Analysing Mathematical Reasoning Abilities of Neural Models." ICLR.

Sugesti, Indri Jati, Risma Simamora, dan Ayu Yarmayani. 2018. "Perbandingan Kemampuan Pemecahan Masalah Matematis Menggunakan Model Pembelajaran Savi Dan Model Pembelajaran Langsung Siswa Kelas Viii Smpn 2
Kuala Tungkal." Jurnal Pendidikan Matematika 2: 9.

Sukirwan, Sukirwan, Darhim Darhim, dan T. Herman. 2018. "Analysis of students' mathematical reasoning." Journal of Physics. https://doi.org/doi :10.1088/17426596/948/1/012036.

Widodo, Tri, dan Sri Kadarwati. 2013. "Higher order thinking berbasis pemecahan masalah untuk meningkatkan hasil belajar berorientasi pembentukan karakter siswa." Jurnal Cakrawala Pendidikan 5 (1).

Wijayanti, Septiana, dan Joko Sungkono. 2017. "Pengembangan Perangkat Pembelajaran mengacu Model Creative Problem Solving berbasis Somatic, Auditory, Visualization, Intellectually." Al-Jabar: Jurnal Pendidikan Matematika 8 (2): 101. https://doi.org/10.24042/ajpm.v8i 2.1941.

Yohansa, Meicheil. 2018. "Perbandingan Kemampuan Pemahaman Matematis Siswa Yang Diajar Menggunakan Model Predict Observe Explain Dan Model Novick Pada Pembelajaran Matematika Di Smp Negeri 20 Jakarta." MATHLINE : Jurnal Matematika dan Pendidikan Matematika 3 (1): 33-46. https://doi.org/10.31943/mathlin e.v3i1.81.

Yusdiana, B., dan Wahyu Hidayat. 2018. "Analisis Kemampuan Penalaran Matematis Siswa Sma Pada Materi Limit Fungsi." Jurnal Pembelajaran Matematika Inovatif 1 (3). https://doi.org/DOI 10.22460/jpmi.v1i3.409-414. 